\title{
Production of Porous Aluminium Using Sodium Chloride
}

\author{
Iva Nová ${ }^{1}, K_{\text {Karel Fraňa }}{ }^{2}$, Jiř́ Sobotka ${ }^{1}$, Pavel Solfronk ${ }^{1}$, David Koreček ${ }^{1}$, Iva Nováková ${ }^{1}$ \\ ${ }^{1}$ Technical University of Liberec, Faculty of Mechanical Engineering, Department, Engineering Technology. E-mail: \\ iva.nova@tul.cz, karel.frana@tul.cz, jiri.sobotka@tul.cz, pavel.solfronk@savs.cz, david.korecek@tul.cz, iva.nova- \\ kova@tul.cz. \\ ${ }^{2}$ Technical University of Liberec, Faculty of Mechanical Engineering, Department of Energy Facilities. Studentská \\ 1402/2, Czech Republic.
}

\begin{abstract}
Our workplace, Technical University of Liberec, is currently engaged in research and production of cellular metal systems. Basically, cellular metal systems are materials with lower density. It is a research in the field of mechanical engineering that is focused on the development of new materials. In general, many methods have been developed for the production of cellular metal systems, e.g. by BANHART [2] or ASHBY [4]. At their production, the direct gassing of molten metals (mostly aluminium ones) or gassing by the powder agents (e.g. specially formulated aluminium powders) are mostly used. Depending on the manufacturing method, a cellular system with open or closed cells can be obtained. The most commonly used metal is aluminium and its alloys. We are currently focusing on the production of porous aluminium by using sodium chloride. Sodium chloride occupies regular sites in the aluminium material and thus contributes to the aluminium porosity. After solidification of the aluminium, sodium chloride is dissolved in water. Sodium chloride is relatively inert to the aluminium and together with it, has a favourable density $\left(2160 \mathrm{~kg} \cdot \mathrm{m}^{-3}\right)$ compared to the aluminium density $\left(2700 \mathrm{~kg} \cdot \mathrm{m}^{-3}\right)$. The values of these physical quantities were observed on the produced aluminium test specimens having $\varnothing 60$ x $10 \mathrm{~mm}$ : relative density of porous system $\rho R E L$; porosity of metal system P; amount of solid phase system volume fraction VPM; density of porous metal system $\rho$ PM and porous material Young's modulus of elasticity EPM.
\end{abstract}

Keywords: Metal System, Porous Metal System, Sodium Chloride, Casting, Aluminium Alloy.

\section{Introduction}

The idea of producing metallic cellular systems (metal foams) dates back to 1926. Other sources, e.g. DE MILLER [1], state that the origin of cellular metal systems dates back to the 1940s. Many patents have been issued since the late 1950 's to 1970 's and many variants of foaming processes have been proposed. As barely anything was ever published besides these patents, it is difficult to evaluate, whether all proposed ideas actually worked. The second rapid increase of the scientific activity started in the late 1980 's and has led to the restoration of some old techniques and has resulted in much higher publishing activity.

Most metal foaming techniques used today have been proposed in the 1950's. Since then, there have been proposed fundamental innovations that are now well known and have led to a variety of processing methods that are constantly reviewed and innovated. A number of new processing methods have been proposed based upon previous developments. Metal cellular systems (porous metals and metal foams) are light-weight cellular metallic materials that in their structure contain pores made by purpose. Their specific structure gives them a very advantageous combination of physical and mechanical properties, such as low density and high stiffness, along with high energy absorption capability.

\section{Metal Cellular systems}

Metal cellular systems are a general term to characterize materials in the state of metallic foams. BANHART [2] highlights the correct identification of metal foam and that there is needed to distinguish between following terms:

Cellular metal systems: the most general term referring to a metal body in which any gaseous cavities are dispersed. The metal phase divides the space into closed cells that contain gas phase.

Porous metal systems (porous foams, porous metals): a special type of cellular metal limited to a certain type of cavities. Pores are usually rounded and isolated from each other.

Metal sponges: morphology of the cellular metal, usually with interconnected cavities.

However, in general all of these systems are in the technical literature referred, without any further indication, under the collective designation of metal foams.

The term porous metal is a general term describing a material with a high porosity, while terms foam metal or metal foam are used for porous metal produced by the melt foaming, where pores are not mutually interconnected (so-called "closed-cell structure"). In addition to that, there is term metal sponge, which is used for highly porous materials in which the pores are connected in quite a complicated manner and the structure cannot be divided into individual cavities (socalled "open-cell structure") [2]. The term metal foam is very often used even in the references as a general designation of porous material.

The production of cell metals in the most general sense, as is described in published literature [2, 3, 4], may not always include the foaming methods. Today, there are various productions that can be divided into different criteria. Depending on the state in which the metal is 
processed, the manufacturing processes can be divided into four groups [3]. Porous metal materials can be made from liquid metal, powdered metal, metal vapour or metal ions. Furthermore, metal processing methodologies within the relevant group are also very important. The porosity can reach from $30 \%$ to $93 \%$, it depends on the manufacturing method and used material. The most commonly used methods for production cellular systems are that ones, where as the starting metal is its melt or powder. Fig. 1 shows methods for producing cellular metallic materials. Some methods are similar to those used for foaming aqueous or polymeric liquids, while others are specifically designed to have the advantage of characteristic metals.

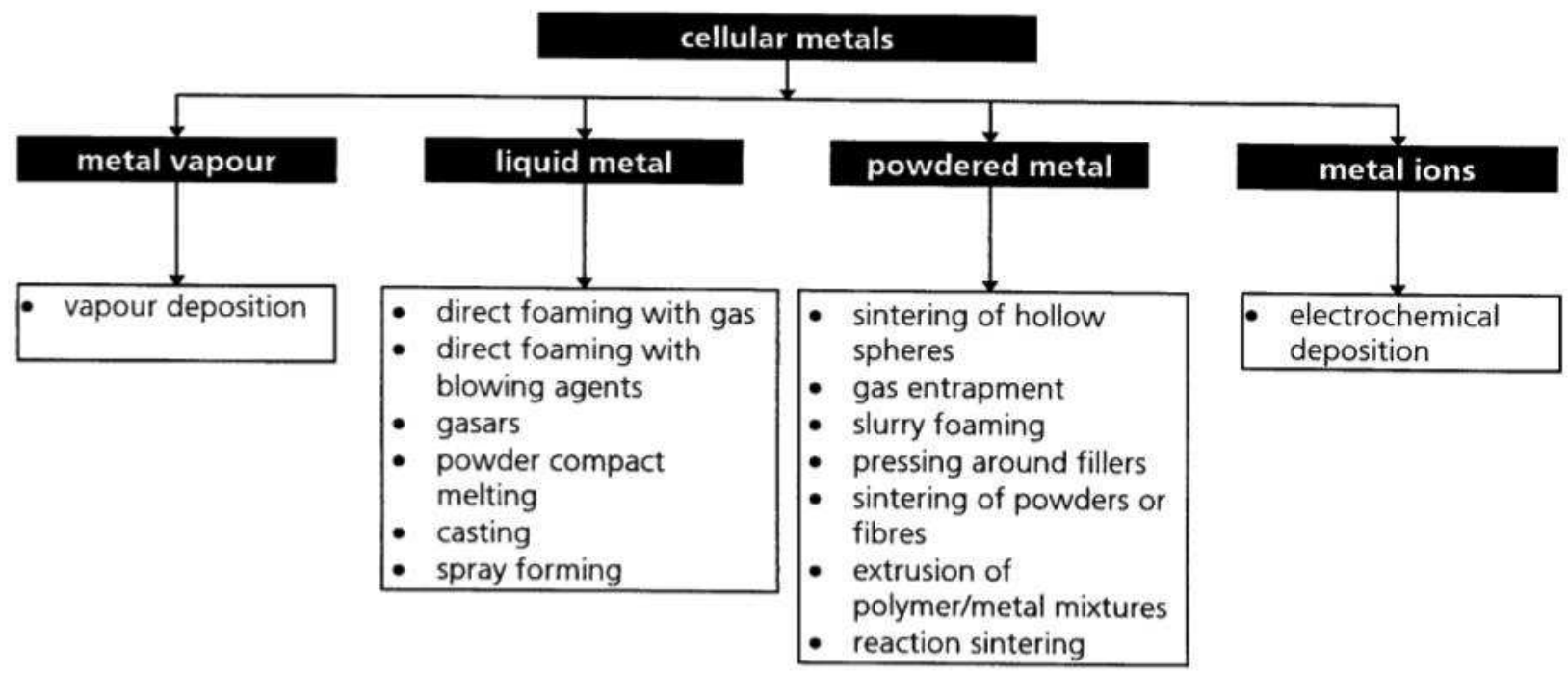

Fig. 1 Overview of the various "families" of production methods for cellular metallic materials, BANHART [3]

One of the important factors for the production metallic cellular systems is reality, whether is used a metal melt or a metal powder (although actual foaming is always done in a liquid state). The second factor is type of agent that creates a cellular structure in the material. It means, if there is gas to make formation of the metal cell structure or if a cellular structure will be made by some bodies. Some methods have been already termed, others characterize "foam" from the producer to its brand name. Depending on the type and parameters of the process, it is possible to obtain a cellular or porous structure of metals with different size, shape and pores arrangement type (regular, irregular). However, production of these cellular materials from aluminium and its alloys is very difficult.

HALBART [2, 3] shows that there are four the most widely used basic types of "metal foams".

a) direct melt foaming,

b) controlled solidification of the melt in an atmosphere of supersaturated gases,

c) powder metallurgy,

d) foundry methods.

Foundry methods are divided into three groups as following:

Lost-mould casting - for the production of these porous castings, there is used a pattern made e.g. from open-cell polymeric foam is used. Metal just follows the shape of e.g. polymeric foam.

Casting of filler material - porous metals can be produced by a method in which the liquid metal is poured into a mould filled with organic or inorganic particles, which can remain in the solidified metal or can be removed by leaching or calcining, even. by other solidification of the metal [8].
Replication process $[8,13,14]$ - this process can be applied in a specially designed jig and represents another way of producing metallic cellular systems. These porous systems (porous castings) are characterized by the experimental simplicity and degree of control over the final porosity of structure. It should be noted that although in the literature are these materials often referred to as foams (but they are not produced by the presence of gas bubbles in the melt), they are more preferably referred to as porous metals or microcell metals [13]. The first report about replication process was issued in the early 1960 's and since then, advance of the research group at the Swiss Federal Institute of Technology in Lausanne have evolved at various stages.

In the foundry processes for the production of aluminium cellular systems, attention should be very paid to their metallurgy, $[15,16]$.

Fig. 2 shows a porous aluminium system manufactured by the Swiss company Exxentis [10].
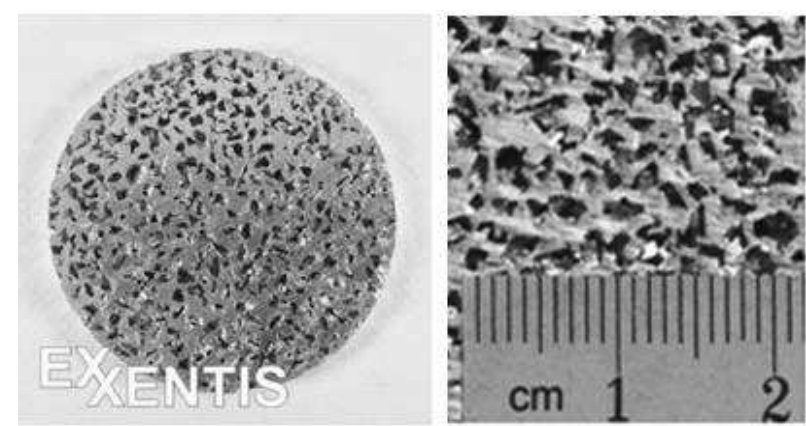

Pore size: $0.63-3.00 \mathrm{~mm}$

Fig. 2 Porous Aluminium System by the Swiss company Exxentis [10] 
The results of our solution for the cellular metal systems should contribute to the possible production of these metal foams in the Czech Republic with a view to their gradual implementation for the production of industrial components.

\section{Experimental part}

\subsection{Preparation and production of aluminium po- rous system (method casting)}

Preparation of aluminium porous system, resp. production of a porous aluminium alloy was combination of a foundry method with utilization of filler material. This material was sodium chloride with a particle size from 2 to $3 \mathrm{~mm}$, see Fig. 3. A special preparation jig (mould) with a cavity $\varnothing 60 \times 150 \mathrm{~mm}$ was used to produce a porous aluminium alloy (see Fig. 4). The jig was filled by a pre-defined amount of "filler material", i.e. sodium chloride. Further, a cylindrical specimen from AlSi12 aluminium alloy (EN AC-44300) was inserted into the jig. After that, the jig (mould) was inserted into a "Classic" resistance furnace. The furnace was heated up to $850{ }^{\circ} \mathrm{C}$. Prior to its insertion into the furnace, the nuts and bolts on the jig were treated with a graphite releasing material so that the jig could be well detached and disassembled after the porous aluminium system was formed. The chemical composition of used aluminium alloy AlSi12 (EN AC-44300) was identified by a Bruker Q4 Tasman optical emission spectrometer - see Tab. 1.

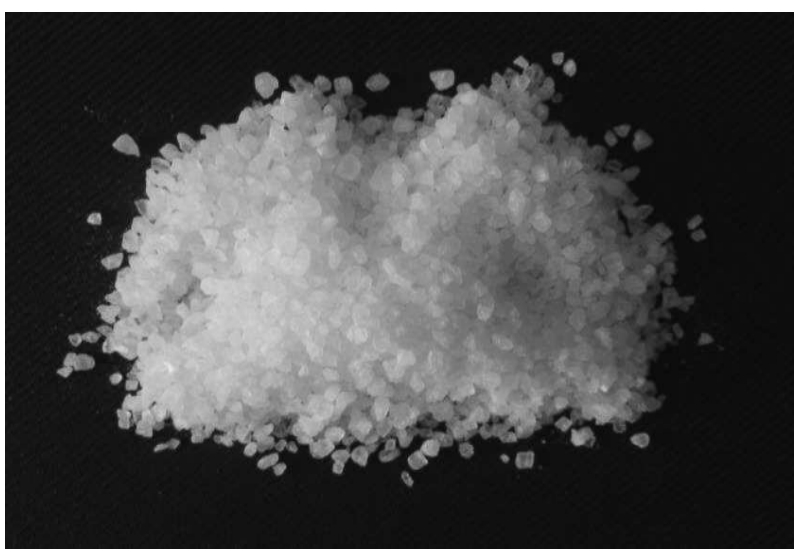

Fig. 3 Sodium chloride used for the production of porous aluminium

Tab. 1 Chemical composition of used AlSi12 aluminium alloy

\begin{tabular}{|c|c|c|c|c|c|c|c|c|c|c|}
\hline \multicolumn{10}{|c|}{ Chemical composition of aluminium alloy EN AC 44300 (AISi12) [wt\%] } \\
\hline $\mathbf{S i}$ & $\mathbf{F e}$ & $\mathbf{M n}$ & $\mathbf{C u}$ & $\mathbf{Z n}$ & $\mathbf{T i}$ & $\mathbf{V}$ & $\mathbf{M g}$ & $\mathbf{N a}$ & $\mathbf{P b}$ & $\mathbf{A l}$ \\
\hline 11.9 & 0.45 & 0.41 & 0.05 & 0.11 & 0.1 & 0.008 & 0.001 & 0.005 & 0.005 & 86.96 \\
\hline
\end{tabular}
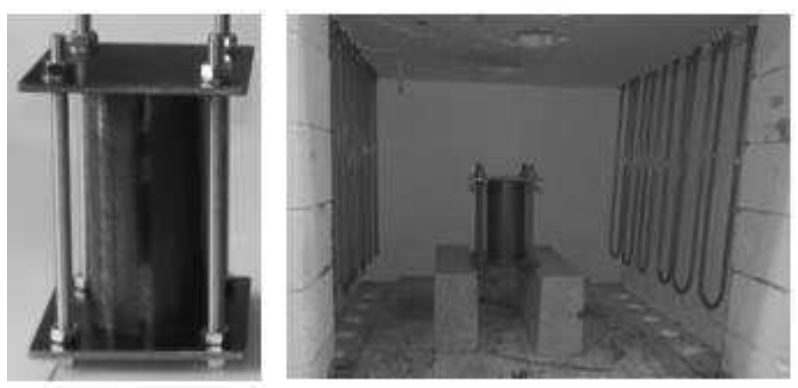

Fig. 4 Preparation jig and furnace for the production of porous aluminium systems
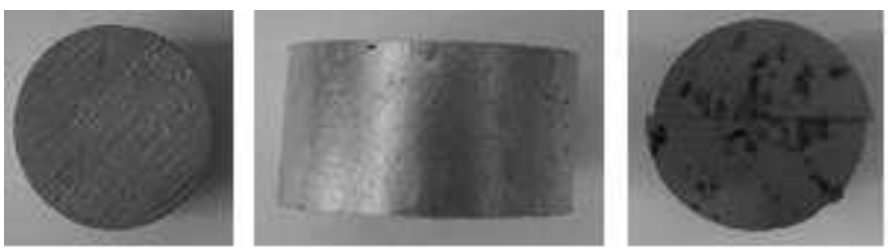

Fig. 5 Sample of pure aluminium for "foaming” ( left) and the macro structure of pure aluminium cellular system samples (right)

\subsection{Preparation and production of an aluminium po- rous system by melt squeeze casting}

Due to previous production failures, further experiments were based on the utilization of melt pressure that was applied into the mould cavity filled with sodium chloride. The foundry mould (see Fig. 6) is made of steel ČSN EN 1.2343 (ČSN19 552) with a cavity of dimensions $\varnothing 60$ x $50 \mathrm{~mm}$. It was needed to develop the necessary
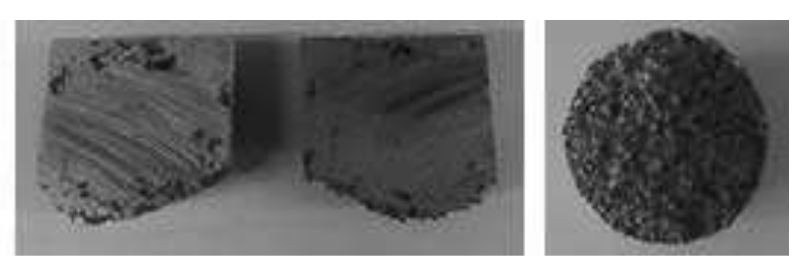

Our experiments are one of the first experiments, so non-standard conditions for the production of porous material AlSi12 was observed. As it can be seen from Fig. 5, the chosen method did not produce the expected results.

The formation of aluminium oxide $\mathrm{Al}_{2} \mathrm{O}_{3}$ very negatively influenced the metallurgy of the aluminium tablet melting in the jig (mould). The performed experiments did not reveal the expected results. Based on thermos-dynamic data of its melting with subsequent oxidation, we concluded that a special device with the possibility of vacuuming the working space and also with the effect of inert gas will be needed for this production. 
by a pressure of $100 \mathrm{MPa}$. In this way, the porous aluminium solid $\varnothing 60 \times 35 \mathrm{~mm}$ was produced.
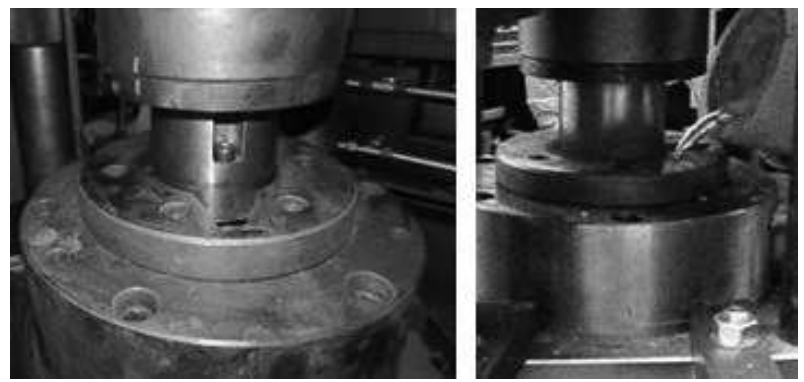

Fig. 6 Equipment for the melt moulding with sodium chloride

After solidification, the porous aluminium solid $\varnothing 60$ x $35 \mathrm{~mm}$ was cut in a transverse direction and placed in a water bath to dissolve the salt. The cross-section macrostructure is shown in Fig. 7. Furthermore, the weight of the produced $10 \mathrm{~mm}$ thick porous sample was monitored. The $10 \mathrm{~mm}$ thickness was chosen because samples of AlSi 12 foam also made by the powder metallurgy and 10 $\mathrm{mm}$ thick were available at our department.

Furthermore, porous material AlSi12 was monitored by using an Olympus DSX 500 microscope. Fig. 8 shows the porosity at different cross sectional areas for AlSi12 aluminium alloy sample.
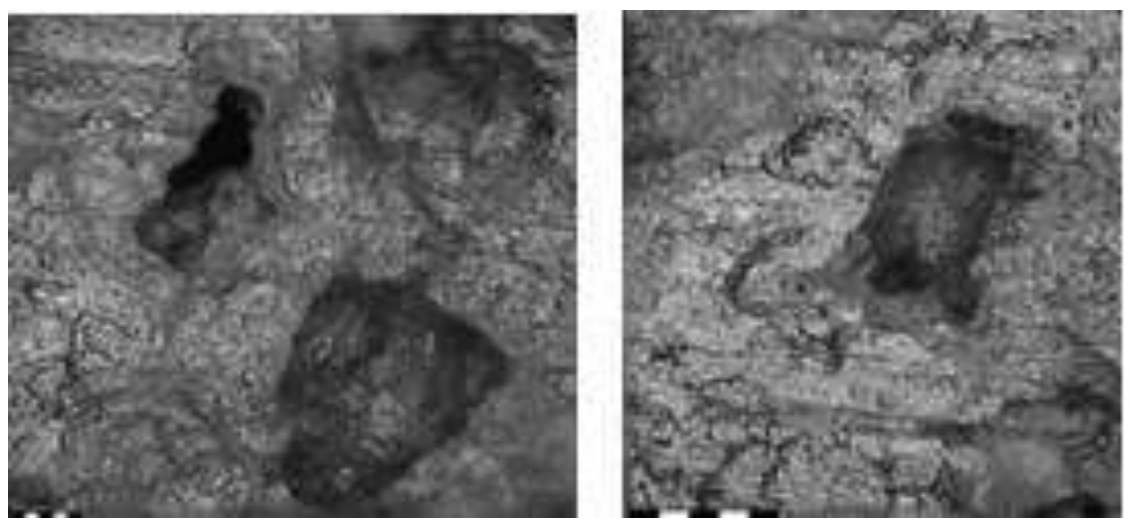

In Fig. 9 is illustrates a porous material of AlSi12 aluminium alloy
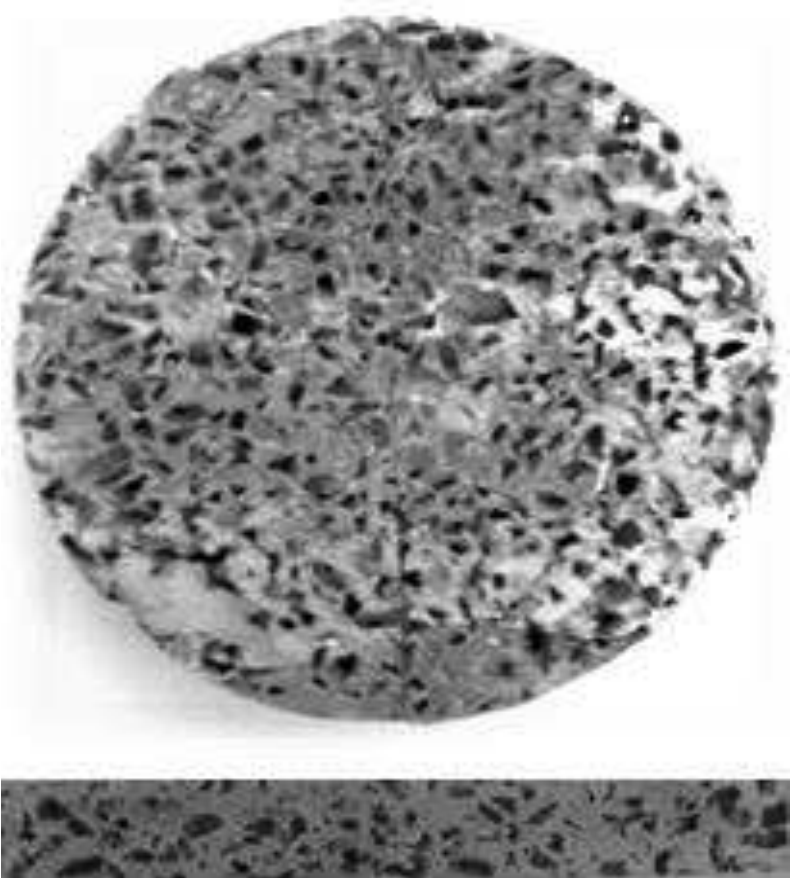

Fig. 7 Cross-section macrostructure of AlSi12 aluminium alloys $\varnothing 60 \times 10 \mathrm{~mm}$ porous samples

Fig. 8 Porosity of a cross-section sample of porous aluminium AlSi12 alloy, monitored by the Olympus DSX 500 microscope (enlargement $5 x$ )
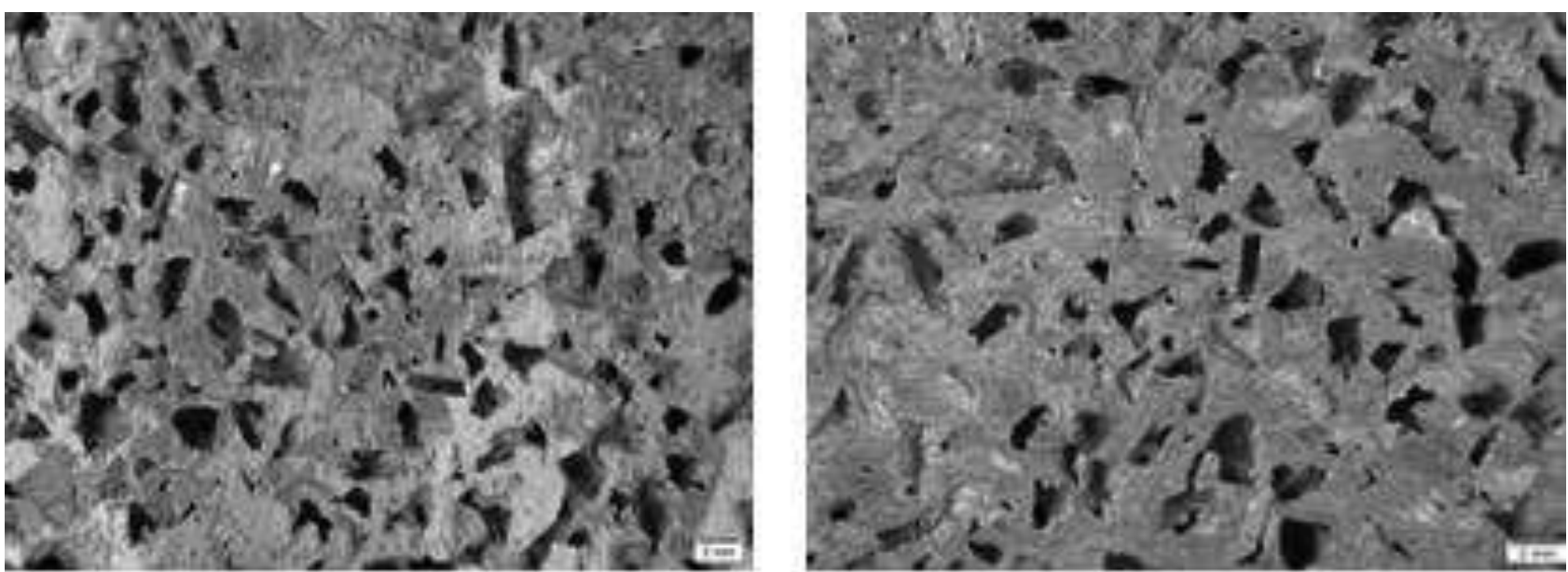

Fig. 9 Porosity of sample aluminium AlSi12 alloys, plan view (enlargement $2 x$ ) 


\subsection{Evaluation of properties of AlSi12 aluminium alloy porous material}

In order to evaluate the properties of the produced aluminium alloy porous system, a methodology was developed to determine its relevant physical-material characteristics, resp. relevant quantities. Used evaluation of the produced aluminium porous materials concerns the determination of the following quantities $[1,15]$ :

Determination the density of porous material $\left(\rho_{P M}\right)-$ it is determined by the physical calculation according to the known following relation:

$$
\rho_{\mathrm{AM}}=\frac{\mathbf{m}_{\mathrm{PM}}}{\mathrm{V}_{\mathrm{PM}}}
$$

Where: $\rho_{\mathrm{PM}}$ is density of porous material $\left[\mathrm{kg} \cdot \mathrm{m}^{-3}\right]$; $\mathrm{m}_{\mathrm{PM}}$ is weight of the porous material $[\mathrm{kg}] ; \mathrm{V}_{\mathrm{PM}}$ is volume of the porous material $\left[\mathrm{m}^{-3}\right]$.

Determination the relative density of the porous material $\left(\rho_{R E L}\right)$ :

$$
\rho_{\mathrm{REL}}=\frac{\rho_{\mathrm{PM}}}{\rho_{\mathrm{BM}}}
$$

Where: $\rho_{\mathrm{REL}}$ is relative density [1]; $\rho_{\mathrm{PM}}$ is density of the porous material $\left[\mathrm{kg} \cdot \mathrm{m}^{-3}\right]$; $\rho_{\mathrm{BM}}$ is density of the base material (without porosity) - AlSi12: $\rho_{\mathrm{BM}}=2660\left[\mathrm{~kg} \cdot \mathrm{m}^{-}\right.$ $\left.{ }^{3}\right]$.

Determination the density of discretized structure of the porous material:

$$
\rho_{\mathrm{AIP}}=\frac{\rho_{\mathrm{BM}} \cdot \mathrm{V}_{\mathrm{PM}}}{\mathrm{V}_{\mathrm{BM}}}
$$

Where: $\mathrm{V}_{\mathrm{PM}}$ is volume of the porous material $\left[\mathrm{m}^{3}\right] ; \mathrm{V}_{\mathrm{BM}}$ is volume of the base material $\left[\mathrm{m}^{3}\right]$.
Determination the porosity of material $(P$ or $\varepsilon)-$ it is the ratio of density difference between base material and porous material (PM) to density of base (non-porous) material $(\mathrm{BM})$ :

$\mathrm{P}=\left(\frac{\rho_{\mathrm{BM}}-\rho_{\mathrm{PM}}}{\rho_{\mathrm{BM}}}\right) \cdot 100[\%]=\left(1-\frac{\rho_{\mathrm{PM}}}{\rho_{\mathrm{BM}}}\right) \cdot 100[\%]$

Determination the Young's modulus of elasticity in porous AlSi12, determined by [15]:

$$
\mathbf{E}_{\mathrm{PM}}=\mathbf{k} \cdot \mathbf{E}_{\mathrm{BM}} \cdot\left(\frac{\rho_{\mathrm{PM}}}{\rho_{\mathrm{BM}}}\right)^{\mathbf{m}}
$$

Where: $E_{P M}$ is Young's modulus of elasticity of porous material (foamed system) [MPa], $\mathrm{E}_{\mathrm{BM}}$ is Young's modulus of elasticity of base material [MPa], $\mathrm{E}_{\mathrm{BM}(\mathrm{AlSi} 12)}$ $=72000[\mathrm{MPa}] ; \rho_{\text {M.P. }}$ and density of porous material $\left[\mathrm{kg} \cdot \mathrm{m}^{-3}\right] ; \rho_{\text {PM }}$ is the density of the porous material $[\mathrm{kg} \cdot \mathrm{m}$ $\left.{ }^{3}\right]$; $\rho_{\mathrm{BM}}$ is the density of the base material $\left[\mathrm{kg} \cdot \mathrm{m}^{-3}\right] ; \mathrm{k}-$ constant for calculation of the modulus of elasticity $\mathrm{k}=$ $(0,1$ to 4$)[15], m$ is the constant for calculation of the modulus of elasticity $\mathrm{m}=2$ [15], $\mathrm{m}=1.5$ to 1.7 [11]. Values were used for the calculation: $\mathrm{k}=0.5 ; \mathrm{m}=2$.

Calculation of the coefficient of thermal conductivity for AlSi 12 material through a relation [15]:

$$
\lambda_{\mathrm{AlP}}=\lambda_{\mathrm{BM}}\left(\frac{\rho_{\mathrm{AlP}}}{\rho_{\mathrm{BM}}}\right)^{\mathrm{a}}
$$

Where: $\lambda_{\text {B.M. }}$ is thermal conductivity of base material AlSi 12: $\lambda_{\text {B.M. }}=150 \mathrm{~W} \cdot \mathrm{m}^{-1} \cdot \mathrm{K}^{-1}$;

$\mathrm{a}-$ constant $(\mathrm{a}=1.65$ to 1.85$)$ [15], $\mathrm{a}=2$ [11].

Based on the equations (1) to (6), the selected values

\begin{tabular}{|c|c|c|}
\hline Property & Designation and value & Value \\
\hline $\begin{array}{l}\text { Density of sample from AlSi } 12 \\
\varnothing 60 \times 10 \mathrm{~mm} \text { (base material) }\end{array}$ & $\rho_{\text {B.M.(AlSi12) }}\left[\mathrm{kg} \cdot \mathrm{m}^{3}\right]$ & 2660 \\
\hline Volume of sample AlSi $12, \varnothing 60 \times 10 \mathrm{~mm}$ (base material) & $\mathrm{V}_{\mathrm{BM}(\mathrm{AlSi} 12)}\left[\mathrm{m}^{3}\right]$ & $2.82 \cdot 10^{-5}$ \\
\hline Weight of sample AlSi $12, \varnothing 60 \times 10 \mathrm{~mm}$ (base material) & $\mathrm{m}_{\mathrm{BM}(\mathrm{AlSi} 12)}[\mathrm{kg}]$ & 0.075 \\
\hline Volume of sample AlSi12 $\varnothing 60 \times 10 \mathrm{~mm}$ (porous material) & $\mathrm{V}_{\mathrm{PM}(\mathrm{AlSi} 12)}\left[\mathrm{m}^{3}\right]$ & $2.89 \cdot 10^{-5}$ \\
\hline Weight of sample AlSi $12 \varnothing 60 \times 10 \mathrm{~mm}$ (porous material) & $\mathrm{M}_{\mathrm{PM}(\mathrm{AlSi} 12)}[\mathrm{kg}]$ & 0.031 \\
\hline Density of sample AlSi12 $\varnothing 60 \times 10 \mathrm{~mm}$ (porous material) & $\rho_{\text {PM (AlSi12) }}\left[\mathrm{kg} \cdot \mathrm{m}^{3}\right]$ & 1074 \\
\hline Relative density of AlSi (porous material) & $\rho_{\text {REL (AlSi12) }}[1]$ & 0.40 \\
\hline Porosity of AlSi $12 \varnothing 60 \times 10 \mathrm{~mm}$ (porous material) & $\mathrm{P}[\%]$ & 60 \\
\hline Young's modulus of elasticity AlSi 12 (porous material) & E PM (AlSi12) [MPa] & 5868 \\
\hline Coefficient of thermal conductivity of AlSi 12 (porous material) & $\lambda_{\mathrm{PM}(\mathrm{AlSi} 12)}\left[\mathrm{W} \cdot \mathrm{m}^{-1} \cdot \mathrm{K}^{-1}\right]$ & 25 \\
\hline
\end{tabular}
of properties for the porous system made of AlSi12 aluminium alloy were calculated. These values are shown in Tab. 3.

Tab. 3 Overview of basic properties - aluminium alloy AlSi 12 porous material

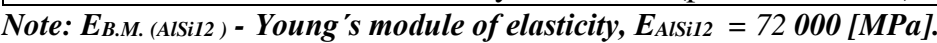

\section{Conclusion}

Production of all cellular metallic materials is associated with the production equipment and the complexity of the technological process. At gasification methods, it is necessary to ensure the homogeneity of the gas bubbles in the material. These complications are e.g. associated with the high oxygen affinity to aluminium. Production is very complex and these materials are produced only by the world-renowned researchers such as e.g. [2, 3, 4, 11] and also by the companies as e.g. Cymat, Alulight, American Elements, Franhofer Institute, LKR, Shinko etc. Similarly, in the production of a porous material, it is necessary to provide a homogeneous distribution of the particles that produce the produced material porosity. The 
methods described in the literature also require additional technological equipment. It has been shown that the utilization of pressing melt into mould containing some $\mathrm{NaCl}$ particles is quite perspective. However, in this case it is necessary to use a moulding press with a pressure range of min. $100 \mathrm{MPa}$ and mould. Simultaneously, the required technological and metallurgical principles must be followed. As it is obvious from Fig 7 the porous structure of the obtained AlSi12 aluminium alloy is comparable to the aluminium alloy produced by the company Exxentis in light of its porosity. The final measured values of the porous AlSi12 material are as following: density $\rho_{\mathrm{PM}}$ (AlSi12) $=1074 \mathrm{~kg} \cdot \mathrm{m}^{-3}$; relative density $\rho_{\text {REL }(\text { AlSi12) }}=0.40$; porosity $\mathrm{P}_{(\mathrm{AlSi} 12)}=60 \%$, Young's modulus of elasticity $\mathrm{E}_{\mathrm{PM}}$ $($ AlSi12) $=5868 \mathrm{MPa}$ and coefficient of thermal conductivity $\lambda_{\mathrm{PM}(\mathrm{AlSi12})}=25 \mathrm{~W} \cdot \mathrm{m}^{-1} \cdot \mathrm{K}^{-1}$. These values correspond to those presented by producers of the porous aluminium [17]. Another possibility of producing aluminium porous materials is to use a vacuum and a shielding atmosphere of argon. However, special equipment is required again. The results of our research should contribute to the possible production of light-weight metal materials in the Czech Republic with the aim of their gradually implementation into the production of industrial components.

\section{Acknowledgement}

The work has been financially supported by the project "Hybrid materials for hierarchical structures", research goal: Composite materials and structures, research program: Materials and structures on the metal basis, reg. no. CZ.02.1./0.0/0.0/16_019/0000843 provided by the European Union and the Czech government.

\section{References}

[1] DE MELLER, M.A. (1926). Produit Métallique Pour L'obtention D'objets Laminés, Moulés Ou Autres, Et Procédés Pour Sa Fabrication. French Patent 615, 147.

[2] BANHART, J. (2000). Manufacturing Routes for Metallic Foams.Journalof Minerals, Metals and Material Society. Vol. 52, No. 12, pp. $22-27$.

[3] BANHART, J. (2001). Manufacture, characterisation and application of cellular metals and metal foams. Progress in Materials Science 46, s. 559-632.

[4] ASHBY, M.F. et al. (2000). Metal Foams: A Design Guide. Ed. Betterwort-Heinemann.

[5] Cymat Corporation Canada. (1998). Product information sheets and foams (http://www.cymat.com).

[6] MIYOSHI, T. et al. (2000). ALPORAS Aluminium Foam: Production Process, Properties and Applications. [online]. Advanced Engineering Materials, , 2, No. 4, s. 179-183.
[7] BAÉZ-PIMIETO, S. et al. (2015). Processing and characterization of open-cell aluminium foams obtained through infiltration process. Procedia Materials Science 9, pp. 54-61.

[8] SURACE, L. DE PHILIPS, L.A.C. LUDOVICO, A.D. BOGHETISCH, G. (2009). Influence of processing an aluminium foam produced by space holder technique. Materials and Design $30 \mathrm{pp}$. $1878-1885$

[9] VOHLÍDAL, J. ŠTULÍK, K. JULÁK, A. (1999). Chemické a analytické tabulky. (Chemical and analytical tables). 1. vyd. Praha: Grada Publishing, ISBN 80-7169-855-5 (in Czech).

[10] Underlying materials of the Exxentis - porous materials Swiss company (2018).

[11] JERZ, J. (1995). Foamed Aluminium and Aluminium Alloys Prepared by Powder Metallurgy. Ph.D thesis, TU Vienna.

[12] HANUS, A. LICHÝ, P and V. BEDNÁŘOVÁ. (2012). Production and properties of cast metal with porous. METAL, Brno Czech Republic, EU.

[13] LUNA, E.M.E. at al. (2014). Casting Protocols for the production of open cell aluminium foams by the replication Technique and the Effect on porosity. Journal of Visualized Experiments. (94), e52568. www.jove. com.

[14] LUNA, E.M.E. (2016). Investigation of Porous Metals as Improved Efficing Regeneration. [Doctoral thesis], The University of Sheffield Faculty of Engineering, March.

[15] MORENO, F.G. (2016) Commercial Application of metal Foams: Their properties and production. Materials, 9. 85, pp. $1-27$.

[16] NANSAARNG, S. and S. SOPHA. (2008) A Synthesis of Aluminium Foams from Ingot by Compessing Meth Method. In. Progresing of the 1 st WSEAS International Conference on Materials science (MATERIALS' 08). ISSN 1790-2769, pp. 130-133.

[17] Technical materials of the company Alumeco Group, Denmark. (www.alumeco.com).

[18] LIPIŇSKI, T. (2017). Analysis of Mechanical Properties of AlSi9Mg Alloy with Al, Ti and B. Manufacturing Technology Vol. 17, No. 5, pp. 761-766, ISSN 1213-2489.

[19] HODINÁŘ, L., SVOBODOVÁ, J., HREN, I., CAIS, J., MICHNA, Š. (2019) The Manganese Influence on the Alloy Al final Bath mechanical Properties Change. Manufacturing Technology Vol. 19, No. 1, pp. 54-63, ISSN 1213-2489. 